\title{
Una semblanza de Margaret Atwood
}

\section{Claudia LUCOTTI Universidad Nacional Autónoma de México}

Si bien en México cada vez que tenemos mucho material y poco tiempo, decimos que todo cabe en un jarrito sabiéndolo acomodar, ofrecer una semblanza de Margaret Atwood en unas cuantas líneas no es tarea fácil. Entonces, ya que existen cientos de libros, artículos, tesis y sitios electrónicos dedicados a ella en donde se puede obtener información puntual sobre su vida y su obra, procuraremos más bien compartir algunas reflexiones más generales en torno a esta autora, prestando particular atención a la pregunta ¿por qué leer a Margaret Atwood en México hoy?

En cuanto a su vida, es importante destacar que, en primer lugar, nace y vive en Canadá, un país que no había figurado de modo particularmente notable en nuestro horizonte pero que en tiempos recientes ha adquirido cada vez más importancia para México. Y no sólo esto, sino que su vida ha tenido como fondo un periodo de la historia de Canadá de lo más interesante y complejo debido a que es cuando este país logra voz y presencia propias muy marcadas. En lo que concierne a cuestiones culturales, por cierto nunca en verdad divorciadas de las políticas, el tema de "lo canadiense", para llamarlo de alguna manera, detonó discusiones muy valiosas, además de que surgieron autores, obras y proyectos influidos por un estar posicionados de otra manera en el mundo, diferente tanto de lo británico como de lo estadounidense, lo cual derivó en formas alternativas de expresarse.

En el caso específico de Atwood, este complejo fondo nacional se combinó con una serie de asuntos, tales como una infancia vivida a medias entre los bosques del norte de su país con un padre entomólogo y un regreso anual a clases en la ciudad donde su mamá mutaba y se vestía de señora; unos años centrales para ella estudiando literatura inglesa en la Universidad de Toronto en donde arreciaban discusiones intensas en torno al papel de la poesía y la figura del poeta en Canadá, y estudios de posgrado en Estados Unidos, cuando descubre la distancia que puede dividir a dos países vecinos. A esto, se va sumando otra serie de vivencias y preocupaciones relacionadas, por ejemplo, con el tema de la mujer, la ecología y los derechos humanos.

Esta rica y compleja realidad suya se refleja en su obra, la cual funge, a su manera, como un mapa o espejo (como bien ha dicho ella sobre la literatura en general) de su mundo y que sin duda resulta de gran interés para quienes la leemos desde fuera. $\mathrm{Su}$ obra es tan numerosa como diversa. Tiene doce novelas, ocho colecciones de cuentos y prosa breve, nueve libros de crítica y ensayo y trece de poesía, además de seis libros 
para niños. Sin embargo, por razones de espacio, sólo mencionaremos algunas características más generales de su escritura.

En su obra destaca, ante todo, una participación y un compromiso notables con el mundo que le tocó y toca vivir a esta mujer canadiense del siglo XX y XXI. A esto se suma una búsqueda permanente por encontrar formas literarias y discursivas nuevas para registrar de modo auténtico su compleja realidad, desechando formas heredadas tradicionales y estereotipadas. La prueba más contundente de que sí halló tanto una forma como una voz propias es que podemos identificar rápidamente una cita de Atwood. Sólo ella puede decir cosas como "I don't know what I'm going to say but I do know what I'm going to wear". Aquí, por cierto, hago un breve paréntesis para simplemente mencionar, sobre todo para un ambiente como el nuestro tan ligado a la traducción literaria, los dilemas a los que nos enfrentamos a la hora de querer traducir a Atwood en México, ya que el decidirse por un registro apropiado del español para sus voces canadienses no es tarea fácil. El que muchas de las traducciones al español de España no nos resulten cómodas complejiza la situación aún más.

Con respecto a esta búsqueda suya por crear a partir de formas propias, hay que decir que Atwood, por lo general, se posiciona y ve desde ángulos imprevistos. Es importante aclarar que esto da por resultado el que no sólo preste atención a aspectos particulares de nuestro mundo que solemos no atender, sino que tiene la osadía y la capacidad de cuestionar e incluso desarticular conceptos y visiones imperantes para introducir variaciones o alternativas a estas formas muchas veces gastadas y que no corresponden a nuestra realidad. Sumado a lo anterior, hay que agregar que su capacidad de observación es asombrosa y que ejemplifica muy bien el comentario de Proust de que un buen escritor tiene todas las cualidades para ser un magnífico espía.

Pero Atwood no sólo ve, también oye. Tiene un oído, un feeling y un timing asombrosos para las palabras, los silencios, las voces diversas, las conversaciones tan sui generis entre seres humanos. Y en su obra no sólo plasma todo esto, sino que se ha vuelto una gran maestra, sobre todo en su poesía, en romper con tradiciones literarias que privilegian una voz solitaria hablando sólo de sí, para ofrecernos creaciones estructuradas a partir de diálogos y entretejidos de voces, lo cual sin duda es un ejercicio muy saludable, hoy y siempre.

Todo esto resulta en una escritura lúcida, luminosa y muy lograda. Pero que, sin duda, pone a trabajar al lector. Leer a Atwood implica un ejercicio imaginativo profundo ya que nos obliga, a través de las imágenes que nos va ofreciendo, a construir universos mentales, emocionales, psicológicos, ricos, complejos, incluso a veces contradictorios, para elaborar respuestas propias. Y para ello no nos ayuda introduciendo recetas o guiones fáciles. Ésta es tarea para el lector, un lector que debe crecientemente dejar atrás una práctica de lectura ingenua, como bien dice en Murder in the Dark, donde de modo muy sugerente compara a un autor con un asesino, al lector con un detective y al libro con la víctima.

Leer pues a una autora comprometida, observadora, lúcida, que no nos simplifica ni nos facilita el mundo sino que nos ofrece una y otra vez creaciones para ejercitar 
todas nuestras capacidades críticas como lectores, no es poca cosa. Y menos para nosotros y nosotras hoy, en un México saturado de discursos y propagandas que ya no nos dicen nada.

Con base en todo lo anterior, no es casual que Atwood haya recibido y siga recibiendo numerosos premios y distinciones, entre los que podemos mencionar, por nombrar sólo algunos, varios Governor General Awards, la distinción literaria más importante de Canadá; el Booker Prize, y el Premio Príncipe de Asturias, además de que su nombre suena cada vez más para el Nobel de Literatura. Por otra parte, ha sido invitada a hablar en $-\mathrm{y}$ ha recibido distinciones por parte de — algunas de las universidades más prestigiosas como NYU, Oxford, Cambridge y La Sorbonne.

En estrecha relación con lo anterior, se inscribe el hecho de que en 2002, cuando la UNAM y el gobierno de Canadá decidieron crear una cátedra extraordinaria dedicada a la cultura canadiense, y ponerle el nombre de las dos escritoras (una de lengua inglesa y una de lengua francesa) más reconocidas de Canadá se pensara de inmediato en Margaret Atwood para las letras inglesas. Atwood, generosamente, aceptó la invitación y en noviembre de ese año, aquí en nuestra Aula Magna, participó en la instalación de dicha cátedra. No hemos olvidado este gesto, ni sus palabras ese día. Por un lado, habló con cariño y admiración de la autora Gabrielle Roy, dándole así su lugar a esta otra gran escritora canadiense, en este caso de lengua francesa, fallecida años antes, y que influyó en muchos escritores más jóvenes de ambas lenguas. Por otro lado, Atwood armó un discurso inaugural efectivo y humorístico a partir de lo que su mente comenzó a pensar y visualizar cuando supo que nuestra universidad le ofrecía ni más ni menos que una "silla" (esto porque en inglés "silla" y "cátedra" se dicen chair). Su discurso fue un ejercicio muy logrado en donde pasó gradualmente de una visión concreta de este mueble con cuatro patas a una reflexión más profunda en torno a la creación de este espacio institucional que permitiría a mexicanos y canadienses conocernos los unos a los otros más y mejor. Aún recuerdo los comentarios de nuestro maestro Colin White, quien por cierto se volvió un gran admirador de Atwood; al concluir la instalación, cómo a partir de una imagen clara y básica, un gran escritor puede elaborar con sus palabras una creación, un producto completo y complejo que nuestras mentes no olvidarán jamás. Colin nos insistía entusiasmado una y otra vez en que tomáramos nota de ello.

Quisiera subrayar un último aspecto de su obra que se vincula con estos distintos impulsos generosos suyos que hemos ido señalando y que consiste en una gran capacidad no sólo de pensar y observar y cuestionar, sino también de ponerse en los zapatos de otros, de sentir con ellos. Sus libros están llenos de ejemplos de esto: tenemos a una madre pensando qué enseñarle a su pequeña hija para que pueda sobrevivir y también vivir en este mundo hoy, a su propio padre ya viejo y enfermo, a los torturados sin nombre de las dictaduras del Cono Sur, a los niños perdidos en un planeta prácticamente en extinción. No fue casualidad sino esta auténtica preocupación por los demás lo que en los años ochentas resultó en una invitación por parte de Amnistía Internacional para dictar una conferencia magistral. Quiero citar sus palabras finales, por dos razones: resumen muy bien su sentir además de que siguen teniendo vigencia hoy. Dice: 


\section{$262 \square$ UNA SEMBLANZA DE MARGARET ATWOOD}

The most lethal weapon in the world's arsenal is not the neutron bomb or chemical warfare; but the human mind that devises such things and puts them to use. But it is the human mind also that can summon up the power to resist, that can imagine a better world than the one before it, that can retain memory and courage in the face of unspeakable suffering. Oppression involves a failure of the imagination: the failure to imagine the full humanity of other human beings. If the imagination were a negligible thing and the act of writing a mere frill, as many in this society would like to believe, regimes all over the world would not be at such pains to exterminate them.

Y luego concluye: "The writer, unless he is a mere word processor, retains three attributes that power-mad regimes cannot tolerate: a human imagination, in the many forms it may take; the power to communicate; and hope".

Ya para finalizar, si retomamos la pregunta inicial de por qué leer a Margaret Atwood hoy en este México tan herido, podemos contestar sin titubeos diciendo que, en resumen, la razón de fondo es que de modos literariamente disfrutables, novedosos y muy logrados nos invita, una y otra vez, a observar y comprometernos con nuestro mundo y a escuchar a los demás con inteligencia crítica, con generosidad, muchas veces con humor y siempre con esperanza, lo cual en estos tiempos es una invitación que se debe agradecer.

\section{Poemas de Margaret Atwood ${ }^{1}$}

\section{You Begin}

You begin this way:

this is your hand,

this is your eye,

this is a fish, blue and flat

on the paper, almost

the shape of an eye.

This is your mouth, this is an $\mathrm{O}$

or a moon, whichever

you like. This is yellow.

Outside the window

is the rain, green

because it is summer, and beyond that

the trees and then the world,

which is round and has only

the colors of these nine crayons.

${ }^{1}$ Estos poemas y sus traducciones están tomados de Las sagradas superficies. Poesía canadiense actual de lengua inglesa. Una mirada a la visión femenina, selec., trad. y pról. de Claudia Lucotti, México, Aldus, 2005. 
This is the world, which is fuller and more difficult to learn than I have said.

You are right to smudge it that way with the red and then the orange: the world burns.

Once you have learned these words you will learn that there are more words than you can ever learn.

The word hand floats above your hand like a small cloud over a lake.

The word hand anchors your hand to this table, your hand is a warm stone I hold between two words.

This is your hand, these are my hands, this is the world, which is round but not flat and has more colors than we can see.

It begins, it has an end, this is what you will come back to, this is your hand.

\section{Comienzas}

Comienzas así:

ésta es tu mano, éste es tu ojo, eso es un pescado, azul y plano sobre el papel, casi con la forma de un ojo.

Ésta es tu boca, ésta es una $\mathrm{O}$ o una luna, lo que prefieras. Esto es amarillo.

Afuera de la ventana está la lluvia, verde porque es verano, y más allá los árboles y luego el mundo, 
que es redondo y sólo tiene

los colores de estas nueve crayolas.

Éste es el mundo, más lleno

y más difícil de aprender de lo que he dicho.

Tienes razón en mancharlo así

con el rojo y luego

el naranja: el mundo arde.

Una vez que hayas aprendido estas palabras

aprenderás que hay más

palabras de las que jamás podrás aprender.

La palabra mano flota sobre tu mano

como una pequeña nube sobre un lago.

La palabra mano ancla

tu mano a esta mesa,

tu mano es una piedra tibia

que sostengo entre dos palabras.

Ésta es tu mano, éstas son mis manos, éste es el mundo, que es redondo pero no plano y tiene más colores de los que podemos ver.

Comienza, tiene un fin, esto es a lo que

regresarás, ésta es tu mano.

\section{Wave}

He was sitting in a chair at dinner and a wave washed over him.

Suddenly, whole beaches were simply gone.

1947. Lake Superior. Last year.

But the cabin, I said, that one, the one with the owldon't you remember? Nothing was left. No feathers. 
We remained to him in fragments.

Why are you so old, he asked me, all of a sudden?

Where is this forest? Why am I so cold?

Please take me home.

Outside the neighbour mowed the lawn.

It's all right here, I said.

There are no bears.

There's food. It isn't snowing.

No. We need more wood, he said.

The winter's on its way. It will be bad.

Ola

Él estaba sentado a la mesa

y una ola le pasó por encima.

De pronto, playas enteras

simplemente desaparecieron.

1947. El lago Superior. El año pasado.

Pero la cabaña, dije, ésa, la de la lechuza-

¿No te acuerdas?

No quedó nada. Ni una pluma.

Permanecimos para él en fragmentos.

¿Por qué estás tan vieja, me preguntó, de golpe?

¿Dónde queda este bosque? ¿Por qué tengo tanto frío?

Por favor llévenme a casa.

Afuera, el vecino cortaba el pasto.

Aquí estamos bien, dije.

No hay osos.

Hay comida. No está nevando.

No. Necesitamos más leña, dijo.

$\mathrm{El}$ invierno viene en camino.

Será muy duro. 


\section{Sor Juana Works In the Garden}

Time for gardening again, for poetry; for arms up to the elbows in leftover deluge, hands in the dirt, groping around among the rootlets, bulbs, lost marbles, blind snouts of worms, cat droppings, your own future bones, whatever's down there supercharged, a dim glint in the darkness. When you stand on bare earth in your bare feet and the lightning whips through you, two ways at once they say you are grounded, and that's what poetry is: a hot wire. You might as well stick a fork in a wall socket. So don't think it's just about flowers. Though it is, in a way.

You spent this morning among the bloodsucking perennials, the billowing peonies, the lilies building to outburst, the leaves of the foxgloves gleaming like hammered copper, the static crackling among the spiny columbines. Scissors, portentous trowel, the wheelbarrow yellow and inert, the grassblades whispering like ions. You think it wasn't all working up to something? You ought to have worn rubber gloves. Thunder budding in the spires of lupins, their clumps and updrafts, pollen and resurrection unfolding from each restless nest of petals. Your arms hum, the hair stands up on them; just one touch and you're struck. It's too late now, the earth splits open, the dead rise, purblind and stumbling in the clashing of last-day daily sunlight, furred angels crawl all over you like swarming bees, the maple trees above you shed their deafening keys to heaven, your exploding syllables litter the lawn. 
Sor Juana trabaja en el jardín

Tiempo de volver a cuidar el jardín; de poesía; de brazos

hasta el codo en restos

de diluvio, manos en la tierra, tanteando

entre raíces, bulbos, canicas perdidas, hocicos

ciegos de gusano, excremento de gato, tus propios huesos

futuros, lo que haya por ahí abajo

sobrecargado, un leve destello en la oscuridad.

Cuando te paras sobre la tierra desnuda

y los rayos te atraviesan, en dos direcciones

a la vez, dicen que estás electrizada,

y eso es la poesía: un alambre caliente.

Como si uno clavara un tenedor

en un socket. Así que no pienses que sólo se trata de flores.

Aunque así es, en cierta forma.

Pasaste la mañana entre las perennes

sedientas de sangre, las ondulantes peonías,

las azucenas por reventar,

las hojas de las dedaleras brillantes como cobre

martillado, la estática crujiente entre los puntiagudos ranúnculos.

Tijera, pala portentosa, la carretilla

inerte y amarilla, las hojas de pasto

murmurando como iones. ¿No crees que todo esto confluía

para algo? Deberías haberte puesto guantes

de hule. Los truenos que brotaban de las torres de los lupinos,

sus racimos y corrientes, polen y resurrección

desdoblándose de cada nido inquieto

de pétalos. Tus brazos reverberan, la piel

de gallina; con sólo tocar sientes la descarga.

Ya es demasiado tarde, la tierra se abre,

los muertos se levantan, ofuscados y tambaleantes

en el clamor de la luz cotidiana del último

día, ángeles peludos se te trepan

como un enjambre de abejas, arriba

los arces esparcen sus notas ensordecedoras

hasta el cielo, tus sílabas

al estallar dejan un tiradero en el césped. 